\title{
Tetramethylpyrazine inhibits the proliferation of acute lymphocytic leukemia cell lines via decrease in GSK-3及
}

\author{
XIAO-JING WANG ${ }^{1,2,3}$, YOU-HUA XU ${ }^{1,2,3}$, GUI-CUN YANG ${ }^{1,2,3}$, HONG-XIA CHEN ${ }^{1,2,3}$ and PING ZHANG ${ }^{1,2,3}$ \\ ${ }^{1}$ Key Laboratory of Developmental Diseases in Childhood, ${ }^{2}$ Key Laboratory of Pediatrics in Chongqing, \\ ${ }^{3}$ Chongqing International Science and Technology Cooperation Center for \\ Child Development and Disorders, Chongqing, P.R. China
}

Received November 3, 2014; Accepted January 14, 2015

DOI: $10.3892 /$ or.2015.3860

\begin{abstract}
Tetramethylpyrazine (TMP) has been proven to be an anticancer agent in many studies. However, its effectiveness in acute lymphoblastic leukemia (ALL) and its molecular mechanisms are still unclear. The present study aimed to evaluate the effect of TMP against Jurkat and SUP-B15 ALL cell lines and to investigate the possible detailed mechanism of action of TMP. A Cell Counting Kit-8 (CCK-8) assay was employed to examine the proliferation of Jurkat and SUP-B15 cells. Flow cytometric analysis was conducted to detect the cell cycle distribution and apoptotic rate. The expression of

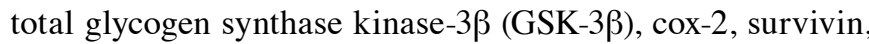
bcl-2 and p27 RNA and protein levels was detected by quantitative real-time PCR and western blot assay, respectively. Additionally, western blot analysis was used to determine the whole-cell and nuclear protein levels of GSK-3 $\beta$ downstream transcription factors, NF- $\kappa \mathrm{B}$ (p65) and c-myc. TMP inhibited the proliferation of Jurkat and SUP-B15 cells in a dose- and time-dependent manner, with $\mathrm{IC}_{50}$ values of 120 and $200 \mu \mathrm{g} / \mathrm{ml}$, respectively at $48 \mathrm{~h}$. TMP induced the apoptosis of Jurkat and SUP-B15 cells and synergistically blocked cell cycle progression at the G0/G1 phase. Cells treated with TMP exhibited significantly attenuated GSK-3 $\beta, N F-\kappa B(p 65)$ and c-myc expression, followed by downregulation of bcl-2, cox-2 and survivin and an upregulation of p27. The results showed that TMP induced apoptosis and caused cell cycle arrest in Jurkat and SUP-B15 cells through the downregulation of GSK-3 $\beta$, which may have further prevented the induced translocation of NF- $\mathrm{KB}$ and c-myc from the cytoplasm to the nucleus.
\end{abstract}

Correspondence to: Professor You-Hua Xu, Key Laboratory of Developmental Diseases in Childhood, Chongqing 400014, P.R. China E-mail: xuyouhua0504@sina.com

Abbreviations: GSK-3 $\beta$, glycogen synthase kinase-3 $\beta$; TMP, tetramethylpyrazine; ALL, acute lymphoblastic leukemia

Key words: tetramethylpyrazine, apoptosis, GSK-3 $\beta$, Jurkat cells, SUP-B15 cells

\section{Introduction}

Glycogen synthase kinase- $3 \beta$ (GSK-3 $\beta$ ) is a multifunctional serine/threonine protein kinase that functions as a transducer in the Wnt/ $\beta$-catenin, Notch, Hedgehog and other signaling pathways to regulate multiple physiological processes, including glycogen metabolism, cell proliferation, differentiation and apoptosis $(1,2)$. GSK-3 $\beta$ is one of the essential cell signal transducers and is recognized for its diverse functions in cell survival (3).

Although its functions in normal cell physiology have been thoroughly investigated, the role of GSK-3 $\beta$ in cancer is still unclear and is the subject of much debate $(4,5)$. In solid tumors, Thiel et al (6) found that treating gastric cancer cells with RNAi targeting GSK-3 $\beta$ or GSK-3 $\beta$ inhibitors induced an increase in cox-2 and promoted the progression of gastric cancer. However, Tsuchiya et al (7) showed that GSK-3 $\beta$ functions as a tumor suppressor in colon cancer by promoting the degradation of $\beta$-catenin. In a previous study of leukemia by our group (8), we demonstrated that GSK-3 $\beta$ is unusually highly expressed in the cytoplasm and nuclei of leukemic cells in children with acute lymphoblastic leukemia (ALL), suggesting that GSK-3 $\beta$ may play a role as an oncogene in ALL. There is a great deal of interest in finding effective drugs directed against GSK-3 $\beta$ for the treatment of various types of cancers (9).

Tetramethylpyrazine (TMP) (2,3,5,6-tetramethylpyrazine; $\mathrm{C}_{8} \mathrm{H}_{12} \mathrm{~N}_{2}$ ) is one of the bioactive ingredients extracted from the rhizome of the Chinese herb Ligusticum. Studies have demonstrated that TMP has potent inhibitory effects on a variety of tumors through affecting the proliferation and migration of tumor cells (10-12). In our previous study, TMP was found to inhibit the growth of HL-60 cells by inducing their differentiation (13). There have been no studies concerning the effect of TMP on ALL cells.

In the present study, we treated Jurkat and SUP-B15 ALL cell lines with TMP and evaluated the effects of TMP on proliferation, apoptosis and the cell cycle. We also analyzed the expression of GSK-3 $\beta$ and its downstream transcription factors and apoptosisrelated molecules in ALL cells in hopes of providing new insight into the anti-leukemia mechanism of TMP.

\section{Materials and methods}

Chemicals and reagents. Both the human acute $\mathrm{T}$ lymphoblastic leukemia Jurkat and $\mathrm{Ph}^{+}$ALL SUP-B15 cells were 
Table I. Primers and annealing temperatures.

\begin{tabular}{|c|c|c|c|}
\hline Primer & Sequences & Size (bp) & Annealing temperature $\left({ }^{\circ} \mathrm{C}\right)$ \\
\hline p27 & $\begin{array}{l}\text { 5'-CGTGTCCTCAGAGTTAGCCG-3' } \\
\text { 5'-GGCAAGTACGAGTGGCAAGA-3' }\end{array}$ & 171 & 58 \\
\hline Cox-2 & $\begin{array}{l}\text { 5'-CCTGCCCTTCTGGTAGAAA-3' } \\
\text { 5'-GGACAGCCCTTCACGTTATT-3' }\end{array}$ & 215 & 58 \\
\hline Survivin & $\begin{array}{l}\text { 5'-AGGACCACCGCATCTCTACAT-3' } \\
\text { 5'-AAGTCTGGCTCGTTCTCAGTG-3' }\end{array}$ & 118 & 64 \\
\hline GSK-3 $\beta$ & $\begin{array}{l}\text { 5'-GGCTACCATCCTTATTCCTCCT-3' } \\
\text { 5'-GTCCACGGTCTCCAGTATTAGC-3' }\end{array}$ & 101 & 64 \\
\hline Bcl-2 & $\begin{array}{l}\text { 5'-CTGCACCTGACGCCCTTCACC-3' } \\
\text { 5'-CACATGACCCCACCGAACTCAAAGA-3' }\end{array}$ & 119 & 61 \\
\hline$\beta$-actin & $\begin{array}{l}\text { 5'-AAGATGACCCAGATCATGTTTGAGACC-3' } \\
\text { 5'-GCCAGGTCCAGACGCAGGAT-3' }\end{array}$ & 191 & 56 \\
\hline
\end{tabular}

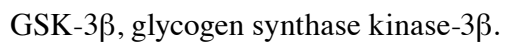

obtained from the American Type Culture Collection (ATCC; USA), and preserved in our laboratory. RPMI-1640 and fetal bovine serum (FBS) were obtained from Gibco and HyClone, USA, respectively. A nuclear and total protein extraction kit and Annexin V-FITC/PI apoptosis detection kit were purchased from KeyGen Biotechnology, China. Western blotting detection reagents and Cell Counting Kit-8 (CCK-8) were obtained from Beyotime Institute of Biotechnology (Jiangsu, China). TMP was purchased in $4 \mathrm{mg} / 2 \mathrm{ml}$ injection ampules from Rongsheng Pharmaceutical Co., Ltd., China. TRIzol reagent was supplied by Life Technologies, USA. Real-time polymerase chain reaction (PCR) primers were synthesized by Huada Biotechnology Co. Ltd., Shanghai, China, and its mixture was obtained from Takara, Japan. Antibodies against GSK-3 $\beta, N F-\kappa B$, c-myc, bcl-2, p2 $7^{\mathrm{KIP} 1}, \beta$-actin and lamin B1 were purchased from Abcam Co., USA. Antibody against survivin was purchased from GeneTex Co., USA.

Cell culture. Both Jurkat and SUP-B15 cells were cultured in RPMI-1640 supplemented with $10 \%$ heat-inactivated FBS, $100 \mu \mathrm{g} / \mathrm{ml}$ streptomycin, $100 \mathrm{U} / \mathrm{ml}$ penicillin and $1 \mathrm{mM}$ L-glutamine. They were maintained at $37^{\circ} \mathrm{C}$ in a humidified atmosphere of $5 \% \mathrm{CO}_{2}$.

Cell proliferation assay. Cell proliferation was detected with the CCK-8 assay following the manufacturer's instructions. Both Jurkat and SUP-B15 cells were seeded at a density of $1 \times 10^{4}$ cells/well in 96-well microtiter plates and cultured for 24,48 and $72 \mathrm{~h}$ with different concentrations of TMP $(20,40$, $80,160$ and $320 \mu \mathrm{g} / \mathrm{ml})$. Control cells were not treated with TMP. At each indicated time point, the cells were combined with $10 \mu \mathrm{l}$ CCK-8 kit solution and incubated for an additional $3 \mathrm{~h}$. Absorbance was measured at $450 \mathrm{~nm}$ (A value). Three replicate wells were used for each analysis. The cell growth inhibition rate (IR) (IR = 1 - A of treated wells/A of control wells) and the half maximal inhibitory concentration $\left(\mathrm{IC}_{50}\right)$ value were calculated.
Cell apoptosis by Annexin V/PI assay. The cell apoptosis rate was measured by flow cytometry (FACSCalibur; BD Biosciences, USA) with Annexin V/PI staining asssay. After being synchronized, Jurkat cells were incubated with TMP $(0,60,120$ and $180 \mu \mathrm{g} / \mathrm{ml})$ for $48 \mathrm{~h}$, while SUP-B15 cells were incubated with TMP $(0,100,200$ and $300 \mu \mathrm{g} / \mathrm{ml})$ for $48 \mathrm{~h}$. Cells $\left(>1 \times 10^{6}\right)$ were collected and washed twice with cold $0.01 \mathrm{M}$ phosphate-buffered saline (PBS). According to the manufacturer's instructions, cells were resuspended in binding buffer and stained with Annexin V-FITC (5 $\mu \mathrm{l})$ and PI $(5 \mu \mathrm{l})$, respectively, and then analyzed by flow cytometry. Early apoptosis was defined as being Annexin V-positive and PI-negative, while late apoptosis and necrosis were defined as being both Annexin V-positive and PI-positive.

Cell cycle assay. The flow cytometric analysis was employed to determine the cell cycle distribution of the TMP treated Jurkat and SUP-B15 cells. Briefly, $\sim 1 \times 10^{6}$ cells were collected. After fixation with $70 \%$ cold ethanol at $-20^{\circ} \mathrm{C}$ overnight, the cells were washed twice with PBS, and labeled with $50 \mathrm{mg} / \mathrm{ml}$ PI containing $100 \mu \mathrm{g} / \mathrm{ml}$ DNase-free RNase A. The cells were cultured for $30 \mathrm{~min}$ at $37^{\circ} \mathrm{C}$ in the dark and analyzed for DNA content by flow cytometry.

Preparation of RNA extraction and quantitative real-time $P C R$ analysis. The expression of GSK-3 $\beta$, c-myc, cox-2, survivin, bcl-2 and p27 mRNA in the TMP-treated Jurkat and SUP-B15 cells was analyzed by quantitative real-time PCR analysis. After the co-culture of cells with TMP at different concentrations for $48 \mathrm{~h}$, total RNAs were isolated using TRIzol reagent according to the manufacturer's protocol. Reverse transcription was used to synthesize complementary DNAs. The primer sequences and annealing temperature used for PCR are listed in Table I. cDNA $(0.8 \mu \mathrm{l})$ was added to $10 \mu \mathrm{l}$ of the PCR mixture containing $3.4 \mu \mathrm{l}$ of $\mathrm{H}_{2} \mathrm{O}, 0.4 \mu \mathrm{l}$ each of $5^{\prime}$ and $3^{\prime}$ primers $\left(10 \mu \mathrm{mol}^{-1}{ }^{-1}\right)$, and $5 \mu \mathrm{l}$ of $2 \mathrm{X}$ SYBR Premix Ex Taq II. 
The reaction conditions were as follows: 39 cycles for $30 \mathrm{sec}$ at $95^{\circ} \mathrm{C}, 5 \mathrm{sec}$ at $95^{\circ} \mathrm{C}, 30 \mathrm{sec}$ at annealing temperature, and $1 \mathrm{~min}$ at $65^{\circ} \mathrm{C}$. The results were normalized against $\beta$-actin and appeared as a target mRNA: $\beta$-actin ratio.

Western blot analysis. Western blot analysis was conducted for GSK-3 $\beta$, c-myc, cox-2, survivin, bcl-2, NF- $\kappa$ B and p27 expression. Jurkat and SUP-B15 cells of the treated and control group were lysed in lysis buffer containing protease inhibitor. According to the nuclear and total protein extraction kit manufacturer's protocol, the following procedures were followed. Nuclear and total protein samples $(100 \mu \mathrm{g})$ were separated on $10 \%$ polyacrylamide resolving gels and $5 \%$ stacking gels and then transferred at $100 \mathrm{~V}$ and $250 \mathrm{~mA}$ for $90 \mathrm{~min}$. The membranes were incubated with primary antibodies overnight at $4^{\circ} \mathrm{C}$. Loading controls of total and nuclear protein samples were confirmed with $\beta$-actin and lamin B1 antibodies, respectively.

Statistical analysis. The results are presented as the mean \pm SEM of three independent experiments. Treated groups were compared with the control group by one-way analysis of variance (ANOVA). $\mathrm{p}<0.05$ was considered to indicate a statistically significant result.

\section{Results}

Effect of TMP on the proliferation of Jurkat and SUP-B15 cells. To investigate the antiproliferative effect of TMP on ALL cells, Jurkat and SUP-B15 cells were exposed to different concentrations of TMP for 24, 48 and $72 \mathrm{~h}$. As shown in Fig. 1, TMP notably inhibited the growth of both cell lines in a dose- and time-dependent manner, although Jurkat cells were more sensitive to TMP. The $\mathrm{IC}_{50}$ values of TMP in the Jurkat and SUP-B15 cells at $48 \mathrm{~h}$ were 120 and $200 \mu \mathrm{g} / \mathrm{ml}$, respectively. Concentrations of 60,120 and $180 \mu \mathrm{g} / \mathrm{ml}$ of TMP were used to treat the Jurkat cells, and concentrations of 100 , 200 and $300 \mu \mathrm{g} / \mathrm{ml}$ were used to treat the SUP-B15 cells in subsequent experiments. The results suggested that TMP is an antitumor agent for human ALL cells.

TMP induces apoptosis in Jurkat and SUP-B15 cells. To confirm whether TMP exerts its inhibitory effect through inducing apoptosis, Jurkat and SUP-B15 cells were incubated with concentration gradients of TMP from 20 to $320 \mu \mathrm{g} / \mathrm{ml}$ for $48 \mathrm{~h}$ and apoptosis was detected by the Annexin V/PI double staining assay using flow cytometry. In Fig. 2, the apoptotic rates of Jurkat cells in the control, 60, 120 and $180 \mu \mathrm{g} / \mathrm{ml} \mathrm{TMP}$ groups were $3.05 \pm 0.05,4.03 \pm 0.2,6.15 \pm 0.3$ and $16.64 \pm 0.65 \%$, respectively, whereas the rates of SUP-B15 cells in the control, 100,200 and $300 \mu \mathrm{g} / \mathrm{ml}$ TMP groups were $2.47 \pm 0.15,4.15 \pm 0.3$, $8.29 \pm 0.29$ and $11.2 \pm 0.3 \%$, respectively. These results indicate that TMP induced apoptosis in the Jurkat and SUP-B15 cells in a dose-dependent manner.

TMP induces G0/G1 cell cycle arrest in the Jurkat and SUP-B15 cells. Based on the evidence of growth inhibition of Jurkat and SUP-B15 cells following TMP treatment, we examined cell cycle distribution using flow cytometry. The results showed that TMP treatment increased the proportion of
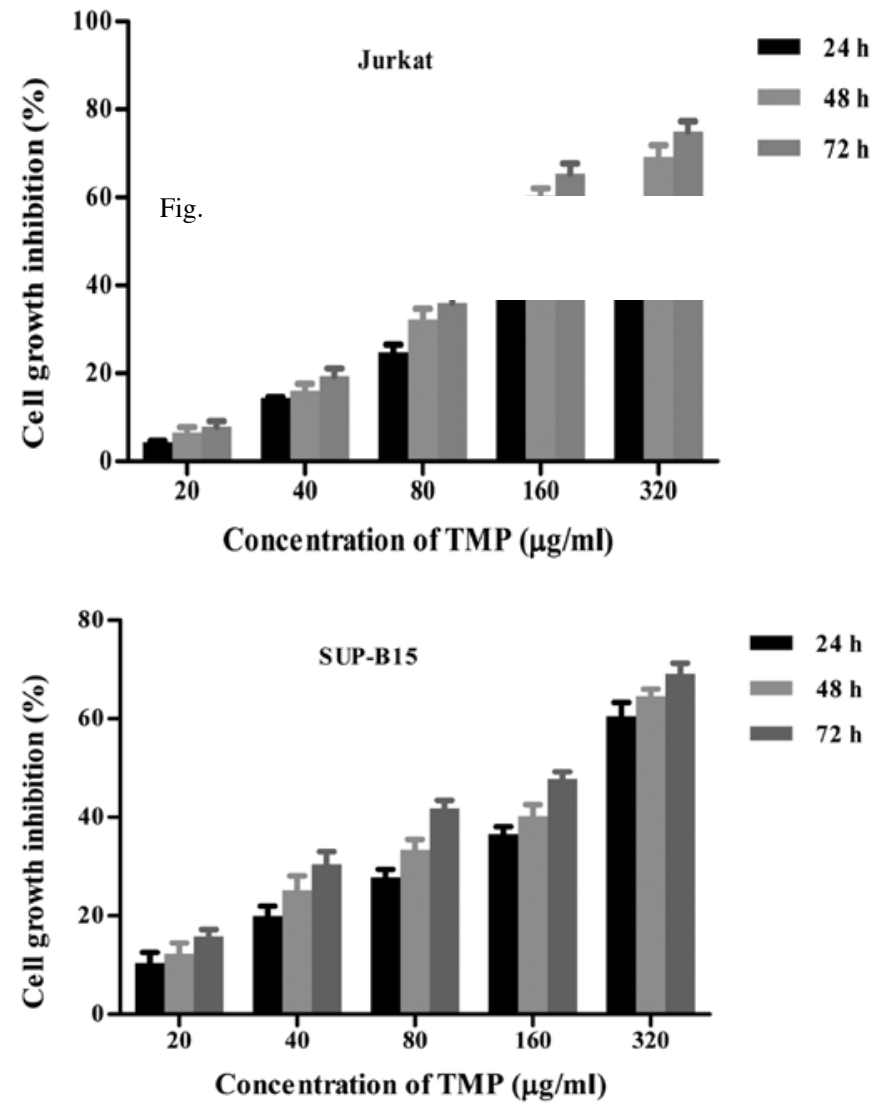

Figure 1. TMP inhibits the growth of ALL cells in a dose- and time-dependent manner. The percentage of cell growth inhibition of Jurkat (upper panel) and SUP-B15 (lower panel) cells treated with concentration gradients of TMP $(20-320 \mu \mathrm{g} / \mathrm{ml})$ for 24,48 and $72 \mathrm{~h}$ are shown. The proliferation of Jurkat and SUP-B15 cells was significantly inhibited by TMP. The results are shown as the mean \pm SEM of three independent experiments in one column. TMP, tetramethylpyrazine.

cells in the G0/G1 phase, whereas it decreased the proportion of cells in the $\mathrm{S}$ and $\mathrm{G} 2 / \mathrm{M}$ phase (Table II).

GSK-3 $\beta$ expression in the TMP-treated Jurkat and SUP-B15 cells. To determine whether GSK-3 $\beta$ participates in the apoptotic induction by TMP, we evaluated the expression of GSK-3 $\beta$ with quantitative real-time PCR and western blot analysis. As shown in Fig. 3, GSK-3 $\beta$ expression decreased significantly both at the protein and RNA levels compared with the control group in the Jurkat and SUP-B15 cells treated with TMP. These results imply a potential inhibitory effect of TMP on GSK-3 $\beta$ expression in ALL.

$T M P$ decreases the expression of GSK-3 $\beta$ downstream of $N F-\kappa B$ and c-myc in the Jurkat and SUP-B15 cells. GSK-3 $\beta$ has been identified to play a vital role in the $\mathrm{NFKB}$ - and c-myc-mediated survival of cancer cells. Since NF- $\kappa$ B and c-myc are downstream transcription factors of GSK-3 $\beta$, we examined the effect of TMP on the levels of NF- $\kappa B$ and c-myc in the Jurkat and SUP-B15 cells. The results showed that the expression of NF- $\mathrm{kB}$ and c-myc in the Jurkat and SUP-B15 cells was decreased in both the whole-cell and nuclear lysates (Fig. 4). These findings suggest that TMP may exert its effect on ALL cell apoptosis 
A (Jurkat) control

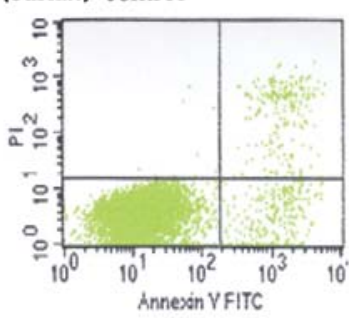

(SUP-B15) control

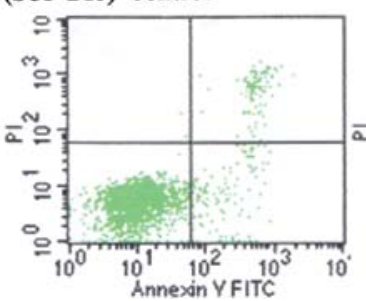

$60 \mu \mathrm{g} / \mathrm{ml}$ TMP

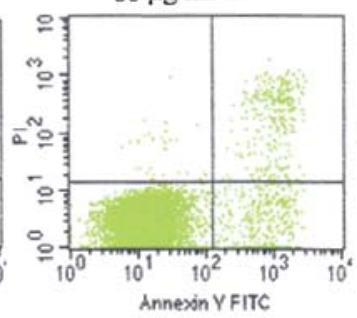

$100 \mu \mathrm{g} / \mathrm{ml}$ TMP

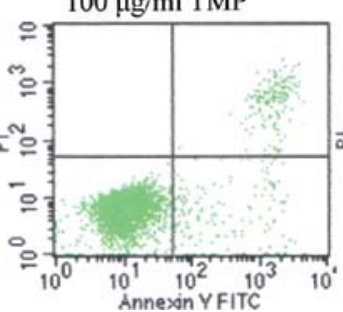

$120 \mu \mathrm{g} / \mathrm{ml}$ TMP

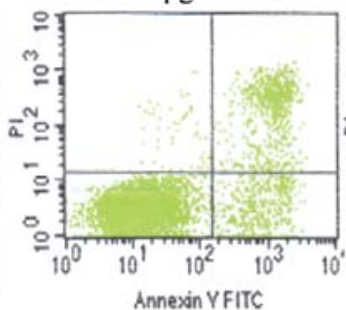

Annexin YFITC

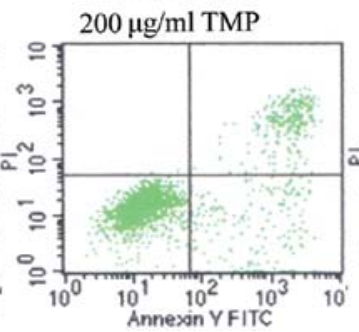

$180 \mu \mathrm{g} / \mathrm{ml}$ TMP

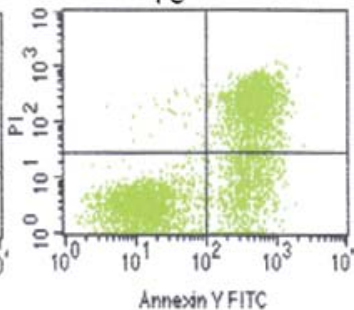

$300 \mu \mathrm{g} / \mathrm{ml}$ TMP

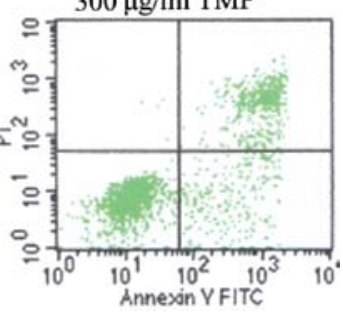

B
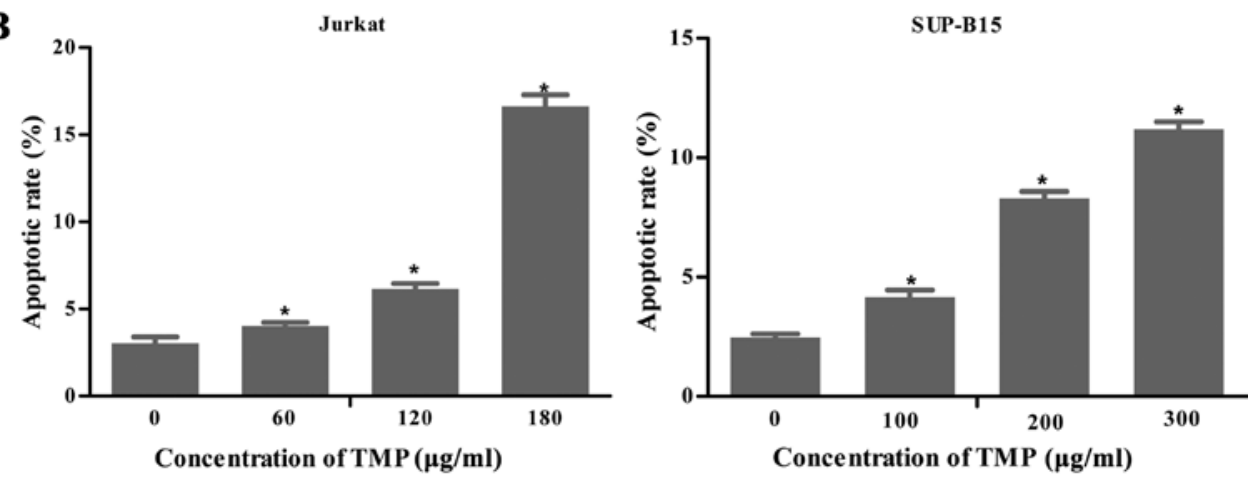

Figure 2. TMP induces apoptosis in Jurkat and SUP-B15 cells. Flow cytometric analysis of TMP-induced apoptosis in Jurkat and SUP-B15 cells using Annexin V-FITC/PI staining. (A) Flow cytometric analysis of Annexin V/PI staining in Jurkat (upper panel) and SUP-B15 (lower panel) cells treated with TMP and control are shown. The concentration of TMP is shown above each plot, and Annexin V/PI staining was performed after a 48-h treatment. The lower right quadrant represents early apoptotic cells, and the upper right quadrant indicates late apoptotic cells undergoing secondary necrosis. (B) TMP induced apoptosis in the ALL cell lines in a dose-dependent manner. " $\mathrm{p}<0.05$ compared with the control cells, which were untreated ' 0 '. TMP, tetramethylpyrazine.
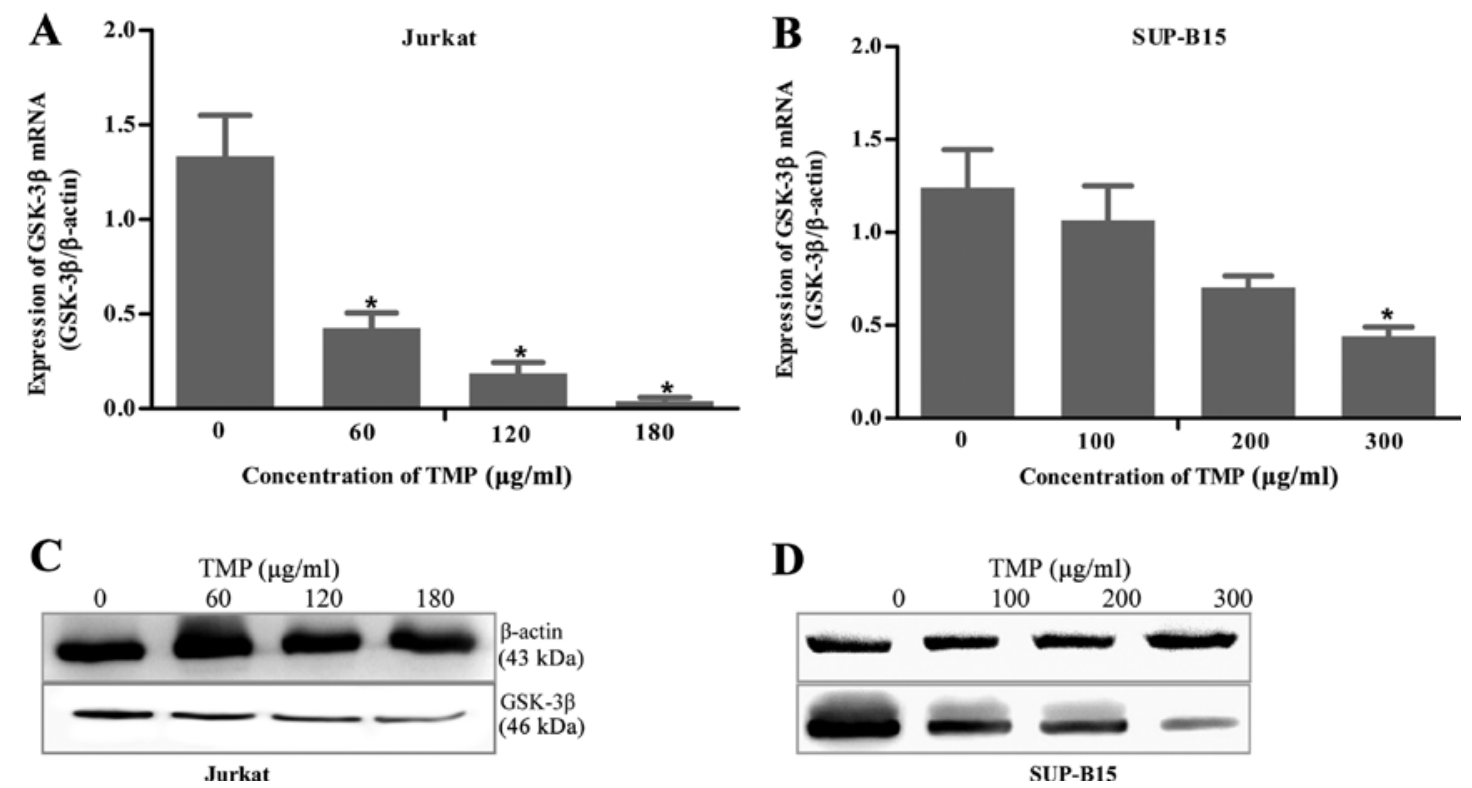

Figure 3. GSK-3 $\beta$ expression in the TMP-treated Jurkat and SUP-B15 cells. (A and B) GSK-3 $\beta$ mRNA levels in the Jurkat and SUP-B15 cells, respectively, following treatment with concentration gradients of TMP as detected by real-time PCR. (C and D) Protein levels of GSK-3 $\beta$ in whole lysates detected by western blotting in the Jurkat and SUP-B15 cells following treatment with TMP, respectively. " $p<0.05$ compared with the control. GSK- $3 \beta$, glycogen synthase kinase-3 $\beta$; TMP, tetramethylpyrazine. 
Table II. TMP causes abnormal cell cycle distribution in the Jurkat and SUP-B15 cells.

A, Jurkat cells

\begin{tabular}{cccc}
\hline & \multicolumn{3}{c}{ Cell cycle distribution (\%) } \\
\cline { 2 - 4 } TMP $(\mu \mathrm{g} / \mathrm{ml})$ & \multicolumn{1}{c}{$\mathrm{G} 0 / \mathrm{G} 1$} & \multicolumn{1}{c}{$\mathrm{S}$} & \multicolumn{1}{c}{$\mathrm{G} 2 / \mathrm{M}$} \\
\hline 0 & $47.07 \pm 3.35$ & $38.88 \pm 1.58$ & $14.05 \pm 1.65$ \\
60 & $54.72 \pm 0.92^{\mathrm{a}}$ & $32.11 \pm 1.9$ & $13.17 \pm 2.20$ \\
120 & $60.05 \pm 4.02^{\mathrm{a}}$ & $30.58 \pm 5.13^{\mathrm{a}}$ & $9.37 \pm 3.45$ \\
180 & $70.83 \pm 1.09^{\mathrm{a}}$ & $26.55 \pm 0.92^{\mathrm{a}}$ & $2.62 \pm 0.45^{\mathrm{a}}$ \\
\hline
\end{tabular}

\section{B, SUP-B15 cells}

\begin{tabular}{cccr}
\hline & \multicolumn{3}{c}{ Cell cycle distribution (\%) } \\
\cline { 2 - 4 } TMP $(\mu \mathrm{g} / \mathrm{ml})$ & $\mathrm{G} 0 / \mathrm{G} 1$ & $\mathrm{~S}$ & \multicolumn{1}{c}{$\mathrm{G} 2 / \mathrm{M}$} \\
\hline 0 & $25.87 \pm 1.09$ & $67.03 \pm 0.92$ & $7.1 \pm 1.65$ \\
100 & $34.05 \pm 4.02^{\mathrm{a}}$ & $59.12 \pm 5.13^{\mathrm{a}}$ & $6.83 \pm 2.20$ \\
200 & $46.84 \pm 2.22^{\mathrm{a}}$ & $47.72 \pm 1.9^{\mathrm{a}}$ & $5.44 \pm 3.45$ \\
300 & $52.47 \pm 1.03^{\mathrm{a}}$ & $43.4 \pm 1.58^{\mathrm{a}}$ & $4.13 \pm 0.45$ \\
\hline
\end{tabular}

${ }^{\mathrm{a}} \mathrm{p}<0.05$, compared with the control. TMP, tetramethylpyrazine.

by downregulating the transcriptional activity of $N F-\kappa B$ and c-myc through GSK-3 $\beta$ regulation.

Effect of TMP on the expression of survivin, bcl-2, cox-2 and p27 in the Jurkat and SUP-B15 cells. Bcl-2, cox-2 and survivin are downstream molecules of NF- $\kappa \mathrm{B}$ or $\mathrm{c}-\mathrm{myc}$ that are relevant for apoptosis, and we evaluated the effect of TMP on their expression levels in the Jurkat and SUP-B15 cells (Fig. 5). The results revealed that bcl-2 and survivin protein expression was decreased significantly in both cell lines after exposure to TMP compared with the control groups, whereas changes in the mRNA levels were not significant. Consistent with the PCR results, the cox-2 protein level was decreased significantly in both the Jurkat and SUP-B15 cells. Considering the fact that TMP resulted in the arrest of Jurkat and SUP-B15 cells in the G0/G1 phase of the cell cycle and $\mathrm{p} 27 /{ }^{\mathrm{Kip} 1}$ regulates and blocks cell cycle progression through the G1-S transition, real-time RT-PCR and western blotting were conducted to examine the p27 expression in the ALL cells (Fig. 5). The results showed that TMP upregulated the expression of p27 in Jurkat and SUP-B15 cells, suggesting a potential mechanism through which TMP affects the cell cycle.

\section{Discussion}

ALL is a heterogeneous group of malignant clonal diseases that originate from pluripotent hematopoietic stem cells. Although improved therapeutic strategies have achieved longterm survival rates of more than $80 \%$ in children, the survival rate is less than $40 \%$ in adults (14). Patients for whom induction chemotherapy fails require intensive chemotherapy and may suffer from severe side-effects of the treatments. Therefore, novel agents are urgently required. The pathogenesis of ALL is the result of multiple factors and genes working in concert. In particular, aberrant cell signal transduction plays a vital role in its occurrence and development. As noted above, GSK-3 $\beta$ acts as an oncogene in ALL and plays an important role in ALL tumorigenesis and progression. In the present study, we adopted GSK-3 $\beta$ as a promising drug target for new, effective and low-toxicity anticancer drugs (15). The small-molecule inhibitors of GSK-3 $\beta$ are mainly divided into two categories: ATP-competitive and non-ATP competitive agents. The former category includes bis-indole and pyrazine, for example, and lithium is a representative of the latter group $(16,17)$. TMP, which is a pyrazine, has been widely used in the clinic for the treatment of cardiovascular and neurovascular diseases $(18,19)$, and it has an excellent safety profile. Recently, beyond its traditional function, TMP has been found to have antitumor effects (20). In the present study, we showed a novel effect of TMP on human Jurkat and SUP-B15 ALL cell lines,
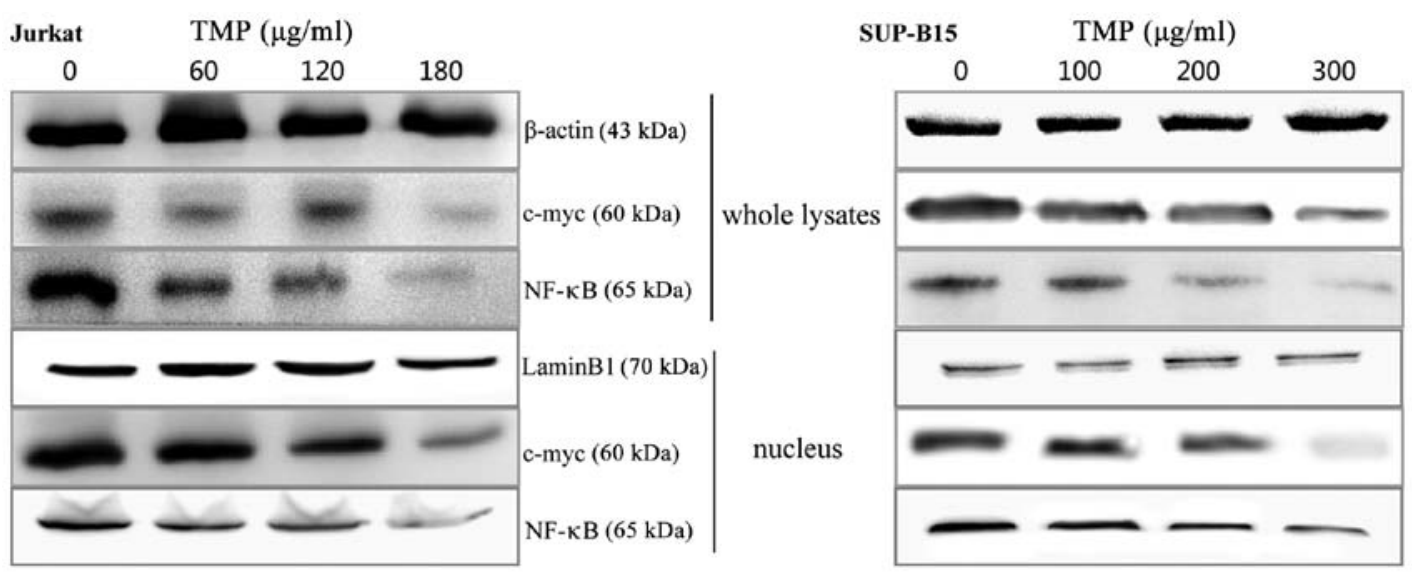

Figure 4. TMP decreases the expression of NF- $\kappa$ B and c-myc in the Jurkat and SUP-B15 cells. The protein levels of NF- $\kappa \mathrm{B}$ (p65) and c-myc in the ALL cell lines detected by western blotting are shown. The expression of NF- $\kappa \mathrm{B}$ and c-myc in the Jurkat and SUP-B15 cells was downregulated in both the whole lysates and in the nucleus. TMP, tetramethylpyrazine. 

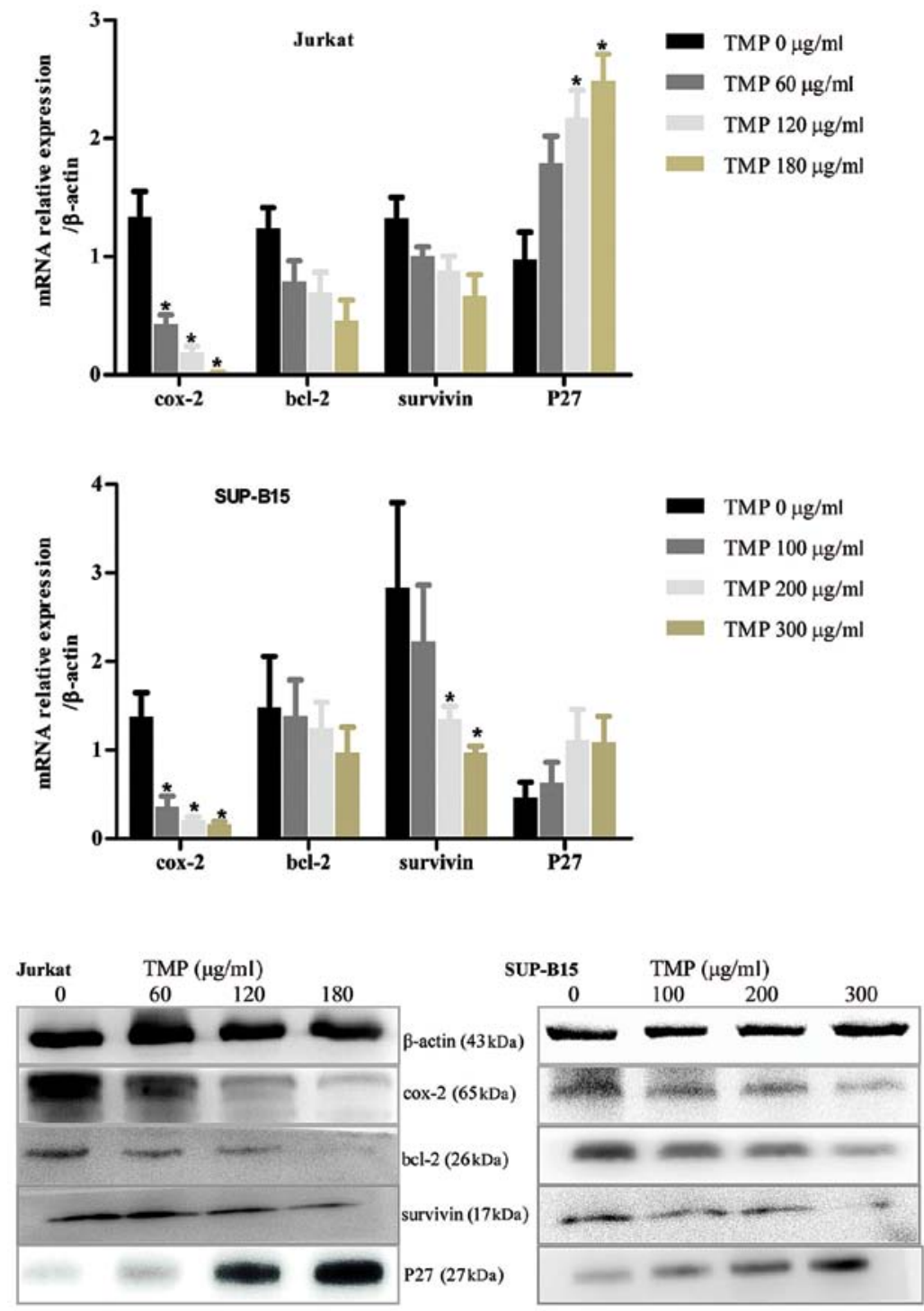

Figure 5. Effect of TMP on the expression of survivin, bcl-2, cox-2 and p27. The downstream molecules of NF- $\mathrm{kB}$ and c-myc, cox-2, bcl-2, survivin and cell cycle protein $\mathrm{p} 27$ were detected by western blotting and real-time PCR. " $\mathrm{p}<0.05$ compared with the control. TMP, tetramethylpyrazine.

i.e., targeting the GSK-3 $\beta$ pathway. Our research found that TMP inhibited the proliferation of Jurkat and SUP-B15 cells in a dose- and time-dependent manner by inducing apoptosis and arresting the cell cycle at the G0/G1 phase. Thus, we report that TMP may be an effective anti-ALL agent. Studies have demonstrated that therapy targeting GSK-3 $\beta$ inhibits the proliferation of several cancer cell lines $(21,22)$. Our experiments showed that GSK- $3 \beta$ expression was significantly decreased in the Jurkat and SUP-B15 cells following treatment with TMP. Therefore, we showed for the first time that TMP exerts antitumor effects on ALL cells by inhibiting GSK-3 $\beta$ signaling.

The substrates of GSK-3 $\beta$ are mainly glycogen synthase and transcription factors such as elf2, HSF-1, c-jun, c-myc and c-myb, among others (23). Here, we found that TMP decreased the total and nuclear expression of transcription factors $\mathrm{NF}-\kappa \mathrm{B}$ and c-myc in the Jurkat and SUP-B15 cells. NF- $\mathrm{kB}$ is a pleiotropic transcription factor that regulates the transcription of its downstream target genes that are critical for the regulation of tumorigenesis, apoptosis and a wide variety of cellular functions (24). In normal cells, NF- $\mathrm{BB}$ is sequestered in the cytoplasm in its inactive form through binding with the

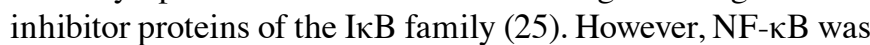
found to be persistently activated in leukemic cells and regulated the anti-apoptotic mechanism (26). Kotliarova et al (27) used GSK-3 $\beta$ inhibitors and RNAi technology to reduce the activity of GSK-3 $\beta$, leading to a decrease in NF- $\mathrm{BB}$ activity, which caused the apoptosis of glioma cells. Ougolkov et al (28) found that the inhibition of GSK-3 $\beta$ activity can silence the expression of the downstream anti-apoptotic target genes of NF- $\kappa$ B in chronic lymphocytic leukemia (CLL) B cells, thereby promoting the apoptosis of CLL B cells. All previous studies suggest that NF- $\kappa \mathrm{B}$ is affected by GSK- $3 \beta$ inactivity.

c-myc, which belongs to the myc family of transcription factors, is a regulator gene that codes for a nucleoprotein that binds to nuclear DNA. By promoting or inhibiting transcription of target genes, c-myc participates in the start of intracellular signal transduction and in the expression of a wide variety of genes (29). C-myc regulates target gene expression by forming a dimer with MAX proteins. Studies have shown that c-myc 
is constitutively highly expressed in acute leukemia (30). Dysfunction of c-myc led to the unregulated expression of many genes, some of which are involved in cell proliferation and apoptosis.

Further experiments in the present study showed that the expression levels of cox-2, bcl-2 and survivin, the downstream target genes of NF- $\mathrm{kB}$ and c-myc, were decreased.

Our previous results showing that the expression of GSK- $3 \beta$ was suppressed by TMP as well as other related literature suggest that GSK- $3 \beta$ may be a potential target for TMP in ALL cells. In our experiments, TMP caused both Jurkat and SUP-B15 cells to be arrested in the G0/G1 phase, which may be associated with an increase in the expression of $\mathrm{p} 27^{\mathrm{KIP} 1} \cdot \mathrm{p} 27^{\mathrm{KIP} 1}$ protein plays a pivotal role in the regulation of the cell cycle as an inhibitor of cyclin-dependent kinases (CDKs) through inhibiting the checkpoint kinase CDK2/ cyclin E1 complex and blocking cell cycle transition from the G0/G1 to the S phase $(31,32)$. The inhibition of GSK-3 $\beta$ has been reported to induce cell cycle arrest at the G1 phase via the activation of $\mathrm{p} 27^{\mathrm{KIPl}}(8)$, which is consistent with our results.

In summary, our experimental results showed that TMP can induce apoptosis in ALL cells by downregulating GSK-3 $\beta$ and TMP 'plays a role as an antitumor agent. TMP, which is an approved treatment option for vascular diseases, exhibits broad potential for the treatment of leukemia, and our results provide a theoretical basis for its clinical application.

\section{References}

1. Doble BW and Woodgett JR: GSK-3: Tricks of the trade for a multi-tasking kinase. J Cell Sci 116: 1175-1186, 2003.

2. Jope RS and Johnson GV: The glamour and gloom of glycogen synthase kinase-3. Trends Biochem Sci 29: 95-102, 2004.

3. Grimes CA and Jope RS: The multifaceted roles of glycogen synthase kinase $3 \beta$ in cellular signaling. Prog Neurobiol 65: 391-426, 2001.

4. Beurel E and Jope RS: The paradoxical pro- and anti-apoptotic actions of GSK 3 in the intrinsic and extrinsic apoptosis signaling pathways. Prog Neurobiol 79: 173-189, 2006.

5. Patel S and Woodgett J: Glycogen synthase kinase-3 and cancer: Good cop, bad cop? Cancer Cell 14: 351-353, 2008.

6. Thiel A, Heinonen M, Rintahaka J, Hallikainen T, Hemmes A, Dixon DA, Haglund C and Ristimäki A: Expression of cyclooxygenase-2 is regulated by glycogen synthase kinase-3beta in gastric cancer cells. J Biol Chem 281: 4564-4569, 2006.

7. Tsuchiya K, Nakamura T, Okamoto R, Kanai $T$ and Watanabe M: Reciprocal targeting of Hath1 and beta-catenin by Wnt glycogen synthase kinase 3beta in human colon cancer. Gastroenterology 132: 208-220, 2007.

8. Hu Y, Gu X, Li R, Luo Q and Xu Y: Glycogen synthase kinase-3 $\beta$ inhibition induces nuclear factor- $\kappa \mathrm{B}$-mediated apoptosis in pediatric acute lymphocyte leukemia cells. J Exp Clin Cancer Res 29: $154,2010$.

9. Wang Z, Smith KS, Murphy M, Piloto O, Somervaille TC and Cleary ML: Glycogen synthase kinase 3 in MLL leukaemia maintenance and targeted therapy. Nature 455: 1205-1209, 2008.

10. Zheng CY, Xiao W, Zhu MX, Pan XJ, Yang ZH and Zhou SY: Inhibition of cyclooxygenase-2 by tetramethylpyrazine and its effects on A549 cell invasion and metastasis. Int J Oncol 40 2029-2037, 2012.

11. Chen L, Lu Y, Wu JM, et al: Ligustrazine inhibits B16F10 melanoma metastasis and suppresses angiogenesis induced by vascular endothelial growth factor. Biochem Biophys Res Commun 386: 374-379, 2009.

12. YiB, Liu D, He M, Li Q, Liu T and Shao J: Role of the ROS/AMPK signaling pathway in tetramethylpyrazine-induced apoptosis in gastric cancer cells. Oncol Lett 6: 583-589, 2013.
13. Wu Y, Xu Y, Shen Y, Wang C, Guo G and Hu T: Tetramethylpyrazine potentiates arsenic trioxide activity against HL-60 cell lines. Braz J Med Biol Res 45: 187-196, 2012.

14. Apostolidou E, Swords R, Alvarado Y and Giles FJ: Treatment of acute lymphoblastic leukaemia: A new era. Drugs 67: 2153-2171, 2007.

15. Naito S, Bilim V, Yuuki K, Ugolkov A, Motoyama T, Nagaoka A, Kato T and Tomita Y: Glycogen synthase kinase-3beta: A prognostic marker and a potential therapeutic target in human bladder cancer. Clin Cancer Res 16: 5124-5132, 2010.

16. Cohen P and Goedert M: GSK3 inhibitors: Development and therapeutic potential. Nat Rev Drug Discov 3: 479-487, 2004

17. Alonso $M$ and Martinez A: GSK-3 inhibitors: Discoveries and developments. Curr Med Chem 11: 755-763, 2004.

18. Li WM, Liu HTHT, Li XY, Wu JY, Xu G, Teng YZ, Ding ST and Yu C: The effect of tetramethylpyrazine on hydrogen peroxideinduced oxidative damage in human umbilical vein endothelial cells. Basic Clin Pharmacol Toxicol 106: 45-52, 2010.

19. Deng L, Guo X, Zhai L, Song Y, Chen H, Zhan P, Wu J and Liu X: Ligustrazine derivatives. Part 4: Design, synthesis, and biological evaluation of novel ligustrazine-based stilbene derivatives as potential cardiovascular agents. Chem Biol Drug Des 79: 731-739, 2012.

20. Yin J, Yu C, Yang Z, He JL, Chen WJ, Liu HZ, Li WM, Liu HT and Wang YX: Tetramethylpyrazine inhibits migration of SKOV3 human ovarian carcinoma cells and decreases the expression of interleukin-8 via the ERK1/2, p38 and AP-1 signaling pathways. Oncol Rep 26: 671-679, 2011.

21. Kawazoe H, Bilim VN, Ugolkov AV, Yuuki K, Naito S, Nagaoka A, Kato T and Tomita Y: GSK-3 inhibition in vitro and in vivo enhances antitumor effect of sorafenib in renal cell carcinoma (RCC). Biochem Biophys Res Commun 423: 490-495, 2012.

22. Thamilselvan V, Menon M and Thamilselvan S: Anticancer efficacy of deguelin in human prostate cancer cells targeting glycogen synthase kinase-3 $\beta / \beta$-catenin pathway. Int $\mathbf{J}$ Cancer 129: 2916-2927, 2011.

23. McCubrey JA, Steelman LS, Bertrand FE, et al: GSK-3 as potential target for therapeutic intervention in cancer. Oncotarget 5: 2881-2911, 2014.

24. Karin M: Nuclear factor-kappaB in cancer development and progression. Nature 441: 431-436, 2006.

25. Aggarwal BB: Nuclear factor-kappaB: The enemy within. Cancer Cell 6: 203-208, 2004

26. Weston VJ, Austen B, Wei W, Marston E, Alvi A, Lawson S, Darbyshire PJ, Griffiths M, Hill F, Mann JR, Moss PA, Taylor AM and Stankovic T: Apoptotic resistance to ionizing radiation in pediatric B-precursor acute lymphoblastic leukemia frequently involves increased NF-kappaB survival pathway signaling. Blood 104: 1465-1473, 2004.

27. Kotliarova S, Pastorino S, Kovell LC, et al: Glycogen synthase kinase-3 inhibition induces glioma cell death through c-MYC, nuclear factor-kappaB, and glucose regulation. Cancer Res 68: 6643-6651, 2008.

28. Ougolkov AV, Bone ND, Fernandez-Zapico ME, Kay NE and Billadeau DD: Inhibition of glycogen synthase kinase-3 activity leads to epigenetic silencing of nuclear factor kappaB target genes and induction of apoptosis in chronic lymphocytic leukemia B cells. Blood 110: 735-742, 2007.

29. Hatakeyama S, Watanabe M, Fujii Y and Nakayama KI: Targeted destruction of c-Myc by an engineered ubiquitin ligase suppresses cell transformation and tumor formation. Cancer Res 65: 7874-7879, 2005.

30. Tomita N: BCL2 and MYC dual-hit lymphoma/leukemia. J Clin Exp Hematop 51: 7-12, 2011.

31. Tapia JC, Bolanos-Garcia VM, Sayed M, Allende CC and Allende JE: Cell cycle regulatory protein $\mathrm{p} 27^{\mathrm{KIP} 1}$ is a substrate and interacts with the protein kinase CK2. J Cell Biochem 91: 865-879, 2004.

32. Porter LA, Kong-Beltran M and Donoghue DJ: Spyl interacts with $\mathrm{p} 27^{\mathrm{Kip} 1}$ to allow $\mathrm{G}_{1} / \mathrm{S}$ progression. Mol Biol Cell 14: 3664-3674, 2003. 